\title{
Relationships between Pleasant Events, Depression, Functionality and Socio-demographic Variables in the Elderly ${ }^{1}$
}

\author{
Heloísa Gonçalves Ferreira², Elizabeth Joan Barham ${ }^{3}$ \\ ${ }^{2}$ Universidade Federal do Triângulo Mineiro, Uberaba-MG,Brazil \\ ${ }^{3}$ Universidade Federal de São Carlos, São Carlos-SP, Brazil
}

\begin{abstract}
Involving the elderly in pleasant activities plays an important role in the prevention and treatment of depression. In addition to the influence of mental health benefits, the frequency of involvement in pleasant activities is also affected by the level of functional dependence and socioeconomic conditions of the elderly. The objective of this study was to investigate relationships between scores of the Brazilian version of an instrument to evaluate the involvement of the elderly in pleasant events (OPPES-BR) and depressive symptoms, functional dependence and socio-demographic variables, to verify the external validity of the OPPES-BR. The sample consisted of 337 non-institutionalized elderly individuals without cognitive impairments, who completed the Beck Depression Inventory, Pfeffer's Functional Activities Questionnaire, Brazil's Economic Classification Criterion and the OPPES-BR. The frequency of involvement in potentially pleasant activities was negatively correlated with depressive symptoms, functional dependence and less favorable socio-demographic conditions, suggesting evidence for the external validity of the OPPES-BR.
\end{abstract}

Keywords: test validity, scaling, elderly, depression

\section{Relações entre Atividades Prazerosas, Depressão, Funcionalidade e Variáveis Sociodemográficas em Idosos}

Resumo: O envolvimento de idosos em atividades agradáveis desempenha importante papel na prevenção e tratamento da depressão. Além da influência da saúde mental, a frequência de envolvimento em atividades agradáveis é afetada pelo nível de dependência funcional e pelas condições socioeconômicas dos idosos. O objetivo deste estudo foi investigar relações entre os escores da versão brasileira de um instrumento para avaliar o envolvimento de idosos em atividades prazerosas (OPPES-BR) e sintomas depressivos, dependência funcional e variáveis sociodemográficas, com o propósito de verificar evidências de validade externa do OPPES-BR. A amostra foi composta por 337 idosos não-institucionalizados e sem comprometimento cognitivo. Foram aplicados o Inventário de Depressão de Beck, a Escala de Atividades Instrumentais da Vida Diária de Pfeffer, o Critério de Classificação Econômica Brasil e o OPPES-BR. A frequência de envolvimento em atividades potencialmente agradáveis apresentou correlações negativas com sintomas depressivos, dependência funcional e condições sociodemográficas menos favoráveis, sugerindo evidências de validade externa do OPPES-BR.

Palavras-chave: validade do teste, escalas, idosos, depressão

\section{Relaciones entre las Actividades Placenteras, Depresión, Funcionalidad y Variables Sociodemográficas en Ancianos}

\begin{abstract}
Resumen: La participación de los ancianos en actividades agradables desempeña un importante papel en la prevención y el tratamiento de la depresión. La frecuencia de participación en actividades agradables también se ve afectada por el nivel de dependencia funcional y las condiciones socioeconómicas de los ancianos. El objetivo de este estudio fue investigar relaciones entre los escores de la versión brasileña de un instrumento para evaluar la participación de ancianos en actividades placenteras (OPPES-BR) y síntomas depresivos, dependencia funcional y variables sociodemográficas, además de verificar evidencias de validez externa del OPPES BR. La muestra fue compuesta por 337 ancianos no institucionalizados y sin compromiso cognitivo. Fueron aplicados el Inventario de Depresión de Beck, la Escala de Actividades Instrumentales de la Vida Diaria de Pfeffer, el Criterio de Clasificación Económica Brasil y el OPPES-BR. La frecuencia de participación en actividades potencialmente agradables presentó correlaciones negativas con síntomas depresivos, dependencia funcional y condiciones sociodemográficas menos favorables, sugiriendo evidencias de validez externa del OPPES-BR.
\end{abstract}

Palabras clave: validación de teste, escalas, ancianos, depresión

'Paper deriving from the doctoral dissertation of the first author, under the supervision of the second author, defended in the Graduate Program in Psychology at the Universidade Federal de São Carlos. Support: São Paulo Research Foundation (FAPESP - Grant nº 2011/00190-9).
Correspondence address: Heloísa Gonçalves Ferreira. Universidade Federal do Triângulo Mineiro. Departamento de Psicologia. Avenida Getúlio Guaritá, $\mathrm{n}^{\circ}$ 159, Nossa Senhora da Abadia, Uberaba-MG, Brazil. CEP 38.025-440. E-mail: helogf@gmail.com 
Good mental health in old age is multidetermined and requires engagement in meaningful activities (Martin et al., 2015). In the elderly population, however, health problems and limited socioeconomic conditions can make it difficult to engage in activities assessed as being enjoyable (Rowe $\&$ Kahn, 1998). The involvement of the elderly in pleasant activities and the relationship between these involvements and lower levels of depression has been documented since the 1970s to the present day by scholars who have developed and evaluated techniques for treating depressed elderly based on behavioral and cognitive behavioral therapies (Lewinsohn \& Libet, 1972, Márquez-González, Losada, Rider, \& López-Pérez, 2014, Rider, Gallagher-Thompson, \& Thompson, 2016). According to this theoretical framework, the frequency of involvement in pleasant events is associated with emotional wellbeing, and there is a direct and negative relationship between the frequency of reinforcing events (events that the individual evaluates as pleasant or agreeable) and degree of depression (Lewinsohn \& Libet, 1972). Therefore, for the treatment of depression, it would be useful to have an instrument to gauge the frequency of a given person's involvement in potentially pleasant activities and the degree to which these activities are perceived as being enjoyable. Such an instrument could be used to identify and measure the involvement of the elderly in situations that could contribute positively to their mental health. An example of such a measure is the California Older Person's Pleasant Events Schedule - COPPES (Rider et al., 2004, 2016), which can be used by therapists to help develop an intervention plan to treat depressed elderly people, aiming to systematically increase the frequency of their involvement in pleasant activities.

Ferreira and Barham (2011) previously documented the benefits of the practice of pleasant activities among the elderly, the lack of Brazilian research on this theme, as well as the lack of validated psychometric instruments for the Brazilian context, that would make it possible to work with this construct. The COPPES (Rider et al., 2004, 2016) was identified by Ferreira and Barham, based on a literature review that was undertaken to find instruments to evaluate the involvement of the elderly in pleasant activities, used in other countries. The COPPES is an American instrument used to measure the frequency of the practice of pleasant activities and the amount of pleasure that the elderly person experiences, when engaged in these activities. This instrument includes 66 items that describe activities that are usually enjoyed by the elderly, in which the respondent must classify the frequency of involvement in the activity over the last month and the subjective pleasure experienced during their involvement in the activity (or that they would have experienced, if they had been involved).

The COPPES has already been validated for the American population, presenting good psychometric properties (Rider et al., 2004, 2016). The scale was used with a sample of 624 adults between 41 to 89 years of age, and presented internal consistency (based on Cronbach's alpha) ranging from .63 to .86 (adequate to very good) for the three subscales
("Frequency", "Pleasure", and "Obtained Pleasure", given that the third score was determined by multiplying the Frequency and Pleasure scores). The scores obtained using this instrument were correlated with the number of depressive symptoms reported by each respondent (evaluated using the Beck Depression Inventory), indicating evidence of external validity. The COPPES covers five domains of potentially enjoyable activities: Socializing, Relaxing, Contemplating, Being Effective, and Being Active. Using this instrument, the therapist can identify the activity domains in which the older person has a greater or lower frequency of involvement and the level of pleasure associated with each domain. With this information, it is possible to prepare an individualized intervention plan, to create the necessary conditions for the older person to increase the frequency of the practice of activities classified as pleasurable, but that are performed with low frequency. In this way, the tool is useful to help elderly people identify activity domains that they find more or less pleasant, helping the client and the therapist to focus their efforts on increasing the frequency of activities in the domains that are the most rewarding.

Given the absence of a validated psychometric instrument for use in the Brazilian context, that could be used to evaluate the involvement of elderly people in pleasant activities, and following an analysis of the evidence of the validity of other instruments, the COPPES was selected to undergo a process of cross-cultural adaptation for use in Brazil (Ferreira \& Barham, 2011). At the end of this process, the researchers concluded that the OPPES-BR (Older Person's Pleasant Events Schedule - Brazilian version) presents satisfactory semantic, idiomatic, cultural and operational equivalence (Ferreira \& Barham, 2013) and excellent evidence of internal consistency (Ferreira, Barham, \& Fontaine, 2015). It should be noted that, for Brazilian elderly, the frequency of involvement in potentially enjoyable activities is divided into four domains: (a) Social and skill-based activities, which includes both social activities and activities that allow the elderly to affirm their sense of competence, utility and self-confidence; (b) Contemplative activities, which refers to activities that are mostly undertaken alone, involving contact with nature and expressing positive feelings; (c) Practical activities, which refers to activities related to involvement with the community or to the daily routine of the elderly; and (d) Intellectual activities, which includes reading or writing activities (Ferreira, 2015).

With respect to evidence of relationships between OPPES-BR scores with external variables, based on preliminary studies, Ferreira et al. (2015) indicated that scores on two of the general subscales of this instrument, namely, Frequency and Obtained Pleasure (the latter is the product of scores on the Frequency and Pleasure subscales), had a negative relationship with the number of depressive symptoms, indicating that the greater the frequency of involvement and the greater the pleasure obtained via these potentially pleasant events, the lower the number of depressive symptoms that the elderly person reports. These results provide evidence about the association 
between OPPES-BR scores and related constructs, since they corroborate the negative association between pleasant events and depression postulated in the behavioral theory of depression that supported the construction of the COPPES and other behavioral scales to measure involvement in pleasant events (Lewinsohn \& Libet, 1972; MárquezGonzález et al., 2014; Rider et al., 2016).

However, the relationship between the four specific domains of potentially enjoyable activities identified in the OPPES-BR and depressive symptoms has not been investigated. The behavioral theory that underpinned the construction of the COPPES (Rider et al., 2004, 2016) led to the investigation of the relationship between elderly people's involvement in pleasant activities and degree of depression. Considering that OPPES-BR is an adaptation of the American scale COPPES, which in turn presented a negative relationship with depressive symptoms (evaluated using the BDI), it becomes relevant to test the existing relations between the domains identified in the Brazilian sample and the same measure of depression, to seek further evidence of the validity of the OPPES-BR, based on the relationship with related constructs.

In addition, it would be important to examine the associations between involvement in pleasant activities and other variables of interest, since sociological and psychological theories of successful aging (Martin et al., 2015, Rowe \& Kahn, 1998) point to the importance of considering elderly people's level of involvement in pleasant activities as a function of psychological variables (such as depression), but also based on the influence of socio-demographic and physical health variables, such as functionality.

For example, Rowe and Kahn (1998) proposed that successful aging is the result of a combination of three factors: (a) maintaining a good level of functionality and presenting a low risk for the development of disabilities; (b) practicing enjoyable and meaningful activities and being engaged with life; and (c) maintaining good physical and cognitive health. Some years later, Neri (2007) also presented a theory of aging and subjective wellbeing, emphasizing the role of sociodemographic variables (such as gender, income, marital status, etc.) in influencing the subjective wellbeing of the elderly, which in turn affect involvement in pleasant activities.

Therefore, the first objective of the current study is to seek additional evidence for the validity of the OPPES-BR, based on relationships with related constructs, by verifying the relationship between the frequency of Brazilian elderly people's involvement in four domains of potentially pleasant events (social and skill-based activities, contemplative activities, practical activities, and intellectual activities) and scores on a measure of depression. This study also aims to verify associations between the frequency of the practice of pleasant activities and: (a) sociodemographic (gender, age, years of study, purchasing power) variables; and (b) functionality (independence in executing instrumental activities of daily life). It is hypothesized that involvement in pleasant activities will have a negative relationship with depression, functionality and also with less favorable sociodemographic conditions.

\section{Method}

\section{Participants}

A total of 337 non-institutionalized elderly people from São Carlos, a medium-sized city in the state of São Paulo, participated in this study. The elderly were selected according to the distribution of the Paulista Social Vulnerability Index (acronym in Portuguese: IPVS) in the city, to guarantee the socioeconomic variability of the sample. The sample was composed with a proportion of participants from each level of IPVS, according to the distribution of the IPVS of São Carlos. The IPVS is used to classify the census sectors of the State of São Paulo, according to their social vulnerability. Social vulnerability is a multidimensional construct that concerns the process of being at risk to reduce the quality of life due to the housing context resulting from inadequate economic, social, psychological, family, cognitive or physical conditions. According to IPVS, six levels of social vulnerability were established: 1 - no vulnerability, 2 - very low vulnerability, 3 - low vulnerability, 4 - medium vulnerability, 5 - high vulnerability, 6 - very high vulnerability.

In the city where the study was carried out, the following percentage distribution of IPVS was observed: no vulnerability $(8.7 \%)$; very low vulnerability $(36.3 \%)$; low vulnerability $(24.8 \%)$; medium vulnerability $(17.5 \%)$; high vulnerability $(8.4 \%)$ and very high vulnerability $(4.2 \%)$.

In the sample of the present study, we sought to achieve a percentage distribution of IPVS that was similar to that observed in the city: no vulnerability $(12.5 \%)$; very low vulnerability $(39.9 \%)$; low vulnerability $(23.4 \%)$; medium vulnerability (14\%); high vulnerability $(6.5 \%)$ and very high vulnerability (3.7\%).

The mean age of participants was 69.7 years, ranging from 60 to 93 years $(S D=7.31)$. In relation to gender, $68.2 \%$ of the sample was female, $31.8 \%$ male. In relation to schooling, $11.5 \%$ of the elderly did not know how to read or write. All participants achieved at least the minimum score in the Mental State Mini Examination (MSME), according to their schooling (Brucki, Nitrini, Caramelli, Bertolucci, \& Okamoto, 2003), indicating that everyone had cognitive ability to respond to the instruments.

\section{Instruments}

Socio-demographic data. A brief questionnaire was prepared for information to describe sample composition, including gender, age, schooling, and marital status.

Brazil's Economic Classification Criteria 2010 - Acronym in Portuguese: CCEB (Associação Brasileira de Empresas de Pesquisa [ABEP], 2010). This measure is used to estimate the purchasing power of urban individuals and families in the country. The higher the score in the instrument, the higher the purchasing power evaluated. This measure was built on the basis of the socioeconomic survey conducted by IBOPE in 2010. An additional proof of the convenience of this measure is its effective discrimination of purchasing power between 
the different Brazilian regions, revealing important differences between them.

Pfeffer's Daily Life Instrumental Activities Scale (Pfeffer, Kurosaki, Harrah, Chance, \& Filos, 1982). This instrument is composed of 10 items that evaluate the ability of the elderly to perform instrumental activities of daily living (IADL), such as preparing meals and shopping. The scores can vary from 0 to 30, and higher scores mean greater dependence on the help of other people to perform daily activities. When adapted and applied in a sample of Brazilian elderly (Assis, 2014), the scale presented excellent internal consistency ( $\alpha$ $=0.91$ ) as well as significant correlations with cognitive and behavioral variables that attest criterion validity.

Beck Depression Inventory II - BDI (Beck, Rush, Shaw, \& Emery, 1979), adapted for use in Brazil by Cunha (2001). This inventory is used to identify depressive symptoms and to estimate the level of depression of the respondent. The instrument consists of 21 items in which the respondent needs to select the sentence that best describes the way he or she felt in the last week. The scores can vary from 0 to 63 points. Higher scores mean higher presence of depressive symptoms. In a validation study for the Brazilian sample (Gomes-Oliveira, Gorenstein, Lotufo Neto, Andrade, \& Wang, 2012), the scale presented high internal consistency $(\alpha=0.93)$ and significant moderate and strong correlations with other measures of depression, presenting evidence of external validity.

Brazilian Version of The California Older Person's Pleasant Events Schedule - OPPES-BR (Ferreira, 2015; Ferreira \& Barham, 2013). This instrument presents 44 items that describe activities that the elderly tend to find pleasant, being composed of a structure of four factors referring to the subscale Frequency: Factor 1 - Social activities and competence $(\alpha=$ 0.94); Factor 2 - Contemplative activities $(\alpha=0.83)$; Factor 3 - Practical activities $(\alpha=0.72)$; and Factor 4 - Intellectual activities $(\alpha=0.70)$. The respondent should indicate the frequency with which he/she performed these activities in the last month, according to a scale that includes the following scores: 0 (never), 1 (1 to 6 times) or 2 (more than seven times). The respondent should also classify the subjective pleasure that he or she experienced in performing each activity, or that he/she would experience if he/she had done it, by means of a scale that can be answered as follows: 0 (was not or would not have been pleasant), 1 (it was either would have been reasonably pleasant) or 2 (it was or would have been quite pleasant). The instrument showed significant correlations with depression, indicating evidence of external validity.

\section{Procedure}

Data collection. Participants were recruited in places frequented by the elderly (community centers, Family Health Units, retirees' associations), or contacted directly in their homes, with the assistance of the professionals who worked in the institutions attended by the participants. In addition, the distribution of the IPVS for the districts of the city was taken into account in order to locate the participants, in order to find a distribution of the IPVS in the sample that was similar to that of the city. The objectives and the conditions of the research were explained before the participant signing the Informed Consent Form. After this stage, the elderly responded first to the MSME. When it was found that the score obtained by the elderly in this instrument indicated absence of cognitive impairment, the participant responded to OPPES-BR and the other instruments. The interviews occurred in the institutions where the elderly person was contacted or at the participant's residence. The interviews were conducted by a psychologist and a professional with training in statistics.

Data analysis. First, descriptive analyses of the variables (averages, standard deviation, minimum and maximum values) were performed. In order to obtain information about external validity of OPPES-BR, statistical correlation tests were performed between the OPPES-BR's scores and the variables of interest (of a continuous nature), using the Pearson correlation coefficient. Additionally, one-way ANOVA was used to verify if there were significant differences between men and women in relation to involvement in pleasant activities. The analyses were performed in IBM SPSS version 19 software.

\section{Ethical Considerations}

This research project was sent to the Research Ethics Committee of the Federal University of São Carlos, and was approved (CAAE: 00713712.4.0000.5504).

\section{Results}

In Table 1, the averages, standard deviations and minimum and maximum values for the continuous and ordinal variables can be visualized.

Table 2 shows the relationships found between the factors that are part of the Frequency subscale and the sociodemographic, functional and psychological conditions of the elderly for the whole sample.

For Factor 1, frequency in Social Activities and Competence expression, we observed statistically significant associations between all variables: significant correlations with age, dependence on instrumental activities of daily living, depressive symptoms, purchasing power and years of study. The greater the involvement in social activities and competence expression, the lower the age, the degree of depression and dependence of the elderly, but the higher the schooling and the purchasing power of the elderly.

As for Factor 2, Contemplative Activities, no significant relationships were found between socio-demographic variables. The frequency in Contemplative Activities showed significant correlations with the dependence on the instrumental activities of daily life and depressive symptoms. The greater the involvement of elderly people in contemplative activities, the lower their degree of functional dependence and depression. 
Table 1

Descriptive Measures of the Variables of the Study

\begin{tabular}{|c|c|c|c|c|c|}
\hline Construct & Instrument or variable & $\begin{array}{l}\text { Average } \\
\text { Score }\end{array}$ & $\begin{array}{l}\text { Standard } \\
\text { deviation }\end{array}$ & $\begin{array}{c}\text { Minimum } \\
\text { value }\end{array}$ & $\begin{array}{c}\text { Maximum } \\
\text { value }\end{array}$ \\
\hline \multirow{3}{*}{$\begin{array}{l}\text { Socio-demographic } \\
\text { conditions }\end{array}$} & Age & 69.66 & 7.28 & 60 & 93 \\
\hline & $\mathrm{CCEB}^{\mathrm{a}}$ & 18.29 & 7.86 & 5 & 40 \\
\hline & Years of study & 5.85 & 5.26 & 0 & 16 \\
\hline Functionality & $\mathrm{AIVD}^{\mathrm{b}}$ & 0.99 & 2.61 & 0 & 20 \\
\hline Psychological conditions & $\mathrm{BDI}^{\mathrm{c}}$ & 8.82 & 7.23 & 0 & 37 \\
\hline \multirow[t]{4}{*}{ Frequency of activities } & Social and Competence Activities & 1.2 & 0.52 & 0 & 2 \\
\hline & Contemplative Activities & 1.66 & 0.32 & 0.79 & 2 \\
\hline & Practical Activities & 1.05 & 0.43 & 0.11 & 2 \\
\hline & Intellectual Activities & 0.84 & 0.67 & 0 & 2 \\
\hline
\end{tabular}

Note. ${ }^{a} \mathrm{CCEB}=$ Critério de Classificação Econômico Brasil (Brazil's Economic Classification Criteria); ${ }^{\mathrm{A}} \mathrm{AIVD}=\mathrm{Atividades} \mathrm{Instrumentais} \mathrm{da}$ Vida Diária (Instrumental Activities of Daily Life); ${ }^{\mathrm{C}} \mathrm{BDI}=$ Inventário de Depressão de Beck (Beck Depression Inventory).

Table 2

Matrix of Correlations between the Four Factors of the Frequency Subscale of OPPES-BR and Socio-demographic, Functional and Psychological Variables

\begin{tabular}{|c|c|c|c|c|c|}
\hline \multirow[b]{2}{*}{ Conditions of the elderly } & \multirow[b]{2}{*}{ Measure } & \multicolumn{4}{|c|}{ Factors of the frequency subscale - OPPES-BR } \\
\hline & & $\begin{array}{c}\text { Social and } \\
\text { Competence } \\
\text { Activities }\end{array}$ & Contemplative Activities & $\begin{array}{l}\text { Practical } \\
\text { Activities }\end{array}$ & $\begin{array}{c}\text { Intellectual } \\
\text { Activities }\end{array}$ \\
\hline \multirow{3}{*}{ Socio-demographic } & Age & $-.11 *$ & .01 & $-.11^{*}$ & -.03 \\
\hline & $\mathrm{CCEB}^{\mathrm{a}}$ & $.29 * *$ & .07 & $.22 *$ & $.62 * *$ \\
\hline & Study & $.26 * *$ & .14 & $.26 * *$ & $.63 * *$ \\
\hline Functionality & $\mathrm{AIVD}^{\mathrm{b}}$ & $-.12 *$ & $-.49 * *$ & $-.17 * *$ & -.00 \\
\hline Psychological & $\mathrm{BDI}^{\mathrm{c}}$ & $-.32 * *$ & $-.29 * *$ & $-.28 * *$ & -.05 \\
\hline
\end{tabular}

Note. ${ }^{*} p<.05 ; * * p<.01 ;{ }^{\mathrm{a} C C E B}=$ Critério de Classificação Econômico Brasil (Brazil's Economic Classification Criteria); ${ }^{\mathrm{b}} \mathrm{AIVD}=$ Atividades Instrumentais da Vida Diária (Instrumental Activities of Daily Life); ${ }^{\circ} \mathrm{BDI}=$ Inventário de Depressão de Beck (Beck Depression Inventory).

Regarding Factor 3, Practical Activities, there were significant correlations between all variables. The frequency in practical activities showed a significant correlation with age, dependence on instrumental activities, symptoms of depression, purchasing power and years of study. The more the elderly are involved in practical activities, the greater their purchasing power and schooling, and the lower their age, degree of depression and functional dependence.

Finally, the factor Intellectual Activities presented significant correlations only with purchasing power and years of study. The greater the involvement of the elderly in intellectual activities, the greater their schooling and purchasing power.

In Table 3, we can observe the averages and the standard deviations separated by gender for the general frequency scores and also for each of the factors. It is noted that there are significant differences between men and women in relation to the frequency of involvement in activities. Women engage more than men in potentially pleasant activities. It is also noted that there are significant differences between genders regarding their involvement in some specific types of activities. It is observed that women reported practicing more contemplative and practical activities than men. There were no significant differences between men and women in terms of involvement in social and competence activities and in intellectual activities.

In addition, gender differences were also observed in the pleasantness experienced when engaging in activities, and women reported experiencing significantly more pleasure than men in engaging in activities included in OPPES-BR. 
Table 3

Averages of the OPPES-BR's scores, by Gender

\begin{tabular}{|c|c|c|c|c|c|c|}
\hline & & & \multicolumn{4}{|c|}{ Factors of the frequency subscale-OPPES-BR } \\
\hline & & $\begin{array}{l}\text { General } \\
\text { Score }\end{array}$ & $\begin{array}{l}\text { Social and } \\
\text { Competence } \\
\text { Activities }\end{array}$ & $\begin{array}{c}\text { Contemplative } \\
\text { Activities }\end{array}$ & $\begin{array}{l}\text { Practical } \\
\text { Activities }\end{array}$ & $\begin{array}{c}\text { Intellectual } \\
\text { Activities }\end{array}$ \\
\hline \multirow{2}{*}{ Average $(\mathrm{S} D)$} & $\begin{array}{c}\text { Men } \\
(\mathrm{N}=106)\end{array}$ & $\begin{array}{l}1.23 * \\
(0.38)\end{array}$ & $\begin{array}{l}1.14 \\
(0.54)\end{array}$ & $\begin{array}{c}1.6^{*} \\
(0.36)\end{array}$ & $\begin{array}{l}0.85^{*} \\
(0.4)\end{array}$ & $\begin{array}{c}0.84 \\
(0.64)\end{array}$ \\
\hline & $\begin{array}{c}\text { Women } \\
(\mathrm{N}=228)\end{array}$ & $\begin{array}{l}1.35^{*} \\
(0.34)\end{array}$ & $\begin{array}{l}1.23 \\
(0.5)\end{array}$ & $\begin{array}{l}1.69^{*} \\
(0.29)\end{array}$ & $\begin{array}{l}1.15^{*} \\
(0.41)\end{array}$ & $\begin{array}{c}0.84 \\
(0.69)\end{array}$ \\
\hline
\end{tabular}

Note. ${ }^{*} p<.05$.

\section{Discussion}

This study aimed to investigate the associations between a measure of practice of pleasurable activities by the elderly (OPPES-BR) with socio-demographic, psychological and functional variables. Significant relationships were observed between frequency in pleasurable activities and age, gender, schooling, purchasing power, depression and dependence on the instrumental activities of daily life in the elderly. The results also attest evidence of OPPES-BR's external validity and will be discussed in detail in the sections that follow.

\section{Socio-demographic Conditions}

It was observed that the socio-demographic conditions of the elderly were associated to all factors of the Frequency subscale, except for Contemplative Activities. These results suggest that schooling, financial condition and the age of the elderly do not limit their access to activities included in the field of contemplative activities, such as expressing positive feelings (for example, smiling at people) and having contact with nature (for example, listening to birds singing, being close to nature). However, the activities described in the other three domains seem to be partially affected by sociodemographic factors, especially the financial conditions and the schooling of the elderly.

Age was the variable that presented the weakest and least significant correlations with the four factors of the OPPES$\mathrm{BR}$, indicating that the involvement in pleasant activities is little affected by age differences among people over 60 years. The correlations presented were limited to two factors - Social and Competence Activities and Practical Activities which included activities (learning about new places, getting involved in community projects and voluntary work, etc.), which generally require greater mobility and physical energy to be spent by elderly, which tends to decline gradually with age.

The OPPES-BR factor that presented higher correlations with sociodemographic conditions (purchasing power and schooling) was involvement in Intellectual Activities. Such a relationship was expected because, in order for the elderly to engage in activities that require reading and writing, they need to have some schooling, which in turn usually predicts greater purchasing power. We can observe that the correlations between involvement in Intellectual Activities and schooling and purchasing power have very similar moderate magnitudes, indicating that such conditions are equally important and probably very related to each other, for the involvement of the elderly in intellectual activities in Brazil.

Years of study and purchasing power also showed associations with involvement in Social and Competence Activities, as well as in Practical Activities. This can be explained by the fact that some items in the Social and Competence Factor describe activities that involve financial costs (for example, visiting a museum, meeting new places, buying new clothes, etc.). Elderly people involved in community projects and voluntary activities (described in the Practical Activities factor) were generally in a better socioeconomic situation, which enabled them to help people in their community.

The results also indicated that there are significant gender differences in the involvement of the elderly in pleasant activities. Women reported engaging more frequently than men in potentially pleasant activities, specifically in the fields of Contemplative Activities and Practical Activities. One of the explanations for these differences is that many of the Contemplative Activities involve expressing positive feelings, whereas Practical Activities include activities related to the home and religious contexts, which are traditionally more common among women. These results also corroborate an earlier study (Márquez-González et al., 2014) that describes the adaptation of COPPES to Spain, where it was found that women presented a higher frequency of involvement in potentially pleasant activities in the general frequency subscale score and in both Being Active and Contemplating domains, which in turn present items in common with the fields Contemplative Activities and Practical Activities of OPPES-BR.

Gender differences were also observed in relation to the pleasure experienced in practicing activities, since women reported feeling more pleasure when engaging in activities. These results are consistent with previous studies (MárquezGonzálezet al., 2014) that demonstrate that there are gender differences in relation to the practice of pleasant activities, indicating that this construct should be evaluated differently for men and women, both in the context of research as well as in clinical context. The results of this study suggest, therefore, that the OPPES-BR's norm groups should be established differentially for the elderly male and female. 
The relationships found between socio-demographic conditions and the practice of pleasant activities by older people also corroborate the Theory of Subjective Well-Being presented by Neri (2007), which emphasizes the role of sociodemographic and socioeconomic variables in influencing the subjective well-being of the elderly, which, in turn, is related to the practice of pleasant activities.

\section{Functionality Conditions}

The findings of this study are in addition to the literature that shows that there is a relationship between practice of activities and functional status of the elderly (d'Orsi, Xavier, \& Ramos, 2011; J. M. Pinto \& Neri, 2013; F. N. Pinto \& Oliveira, 2015), being consistent with the theory of successful aging presented by Rowe and Kahn (1998) and reviewed by Martin et al. (2015), which indicates that there is an association between life engagement (which includes the practice of pleasant activities) and a low risk of disability.

Dependence on the instrumental activities of daily life has been associated more strongly with the practice of contemplative activities, indicating that the more functional dependence on instrumental activities, the less will be the involvement of the elderly in contemplative activities. These results are somewhat surprising, since the domain of contemplative activities includes those that require less physical and cognitive effort, and therefore, even the elderly with lower functional capacity would be able to engage in this type of activity. However, we must also consider that the sample of this study is composed in its entirety by elderly people who do not present cognitive impairment, besides the sample average in the Pfeffer Index indicate absence of dependence on the instrumental activities. Therefore, the relationships between the domains of pleasant activities and dependence on instrumental activities are being observed in the elderly, who, for the most part, had their functional capacity relatively preserved.

One possible explanation for the observed association between functionality and involvement in Contemplative Activities is that this domain includes activities of expression of positive feelings. It may be that there is a reduction in the frequency of expression of positive affects, as the elderly person loses his functional capacity, since this decline influences his satisfaction with life (Sato, Demura, Kobayashi, \& Nagasawa, 2002).

The associations between functionality and the fields of Social and Competence Activities, as well as Practical Activities were significant, but weaker, probably because it was a sample in which the elderly still had good functional capacity, so that this variable did not interfere to a great extent in the involvement in these activities. The absence of association between functional status and involvement in activities of the Intellectual Activities domain can be explained by the fact that all the elderly in the sample presented preserved cognitive abilities. Among those older people, engaging in intellectual activities seems to be independent of the functional state.
Other Brazilian researchers have also demonstrated that the involvement of the elderly in activities is affected by functional status. Based on a cross-sectional study with 2472 elderly Brazilians, Pinto and Neri (2013) reported significant correlations between involvement in social activities and functional capacity. Already in a longitudinal study with 326 elderly Brazilians, d'Orsi et al. (2011) showed that activities with friends, watching TV and manual activities appeared as protective factors for the loss of functionality. However, the relationship between involvement in pleasant activities with functionality still needs to be further investigated, especially regarding the causal direction between these variables, and for that, more longitudinal studies are needed.

\section{Psychological Conditions}

Depression was associated with all factors of the frequency subscale, except for the factor comprising Intellectual Activities. The strongest correlation observed with depression was with the Social Activities and Competence factor, which is the domain that most includes activities with interpersonal interactions. This result suggests that variations in the social involvement of the elderly are more related to depression in old age than the frequency in activities of other domains, corroborating Brazilian data reported by Alvarenga, Oliveira and Faccenda (2012), who affirm that there is a relationship between depression and the practice of social activities, although it is not yet possible to state the cause and effect direction between these variables.

The frequency of involvement in activities in the fields of Contemplative Activities and Practical Activities were also related todepression, buttoalesserextent thanactivitiesincluded in the field of Social and Competence Activities. Therefore, for the treatment of depression in Brazilian elderly, it seems relevant to focus more attention on increasing the frequency of social activities and expressing a sense of competence and usefulness, but also activities to express positive feelings and contact with nature (linked to the domain of Contemplative Activities), and activities related to community and home involvement (linked to the field of Practical Activities). The significant relationships found between depression with social and competence, contemplative and practical activities also corroborate the initial findings of Lewinsohn and Graf (1973) on the most relevant categories of pleasant events to take into account in the treatment of depression: positive social interactions, expression of positive feelings and activities that express a sense of competence.

The domain of Intellectual Activities probably had no relation to depression since this category did not include activities that necessarily express contact with other people, expression of positive feelings and usefulness, components normally associated with the diagnosis of depression (absence of pleasure and social contact, feelings of guilt and uselessness, etc.). The results of this study suggest that the frequency of practice of intellectual activities among the elderly does not seem to play a central role to relieve or prevent the depressive symptoms in Brazilian culture. 
The findings of the present study also corroborate the results found by Rider et al. (2016) when describing the validation process of COPPES in the USA, presenting the relationship between depression scores and frequency of practice of pleasant activities. The negative relationship between the OPPES-BR's scores and depression scores also confirm the behavioral theory of depression that underpinned the construction of the American instrument (Lewinsohn \& Libet, 1972), indicating evidence of OPPES-BR validity regarding external variables.

It is hypothesized that the involvement of the elderly in pleasant activities, a construct originally operationalized by the behavioral sciences, may also be associated with other psychological constructs such as subjective well-being, life satisfaction and quality of life. Although the results of this and other studies (Ferreira et al., 2015) have already provided evidence of OPPES-BR validity regarding relations with external variables (in this case, depressive symptoms), demonstrating that the adapted scale can be used in a clinical context for the treatment of depression, we consider that it is still relevant to continue evaluating the relationship between OPPES-BR scores and other variables of interest (positive psychological constructs, socio-demographic and functional variables), especially with regard to the causal relationships between these variables.

For this reason, longitudinal studies are still necessary to better elucidate the relationships observed in this study. Investigations involving more sophisticated techniques of multivariate data analysis (such as Modeling Structural Equations) would also be relevant to investigate the mediating or moderating role of socio-demographic variables and functionality in the relationship between pleasant events and depression. Studies to investigate the relationship between pleasant events and positive psychological constructs (life satisfaction, quality of life, subjective well-being) are also important and could bring more evidence of convergent OPPES-BR validity.

Considering that the psychometric properties of OPPESBR have been investigated in greater depth, we can anticipate that this is an instrument that can help in the understanding of psychological processes that lead the elderly people to engage in more or less potentially pleasant activities, considering their conditions of life. This instrument will be of great relevance for researchers interested in investigating the involvement of Brazilian elderly in pleasant events, besides being useful for interventions focused on promoting the well-being of these elderly people.

\section{References}

Alvarenga, M. R. M., Oliveira, M. A. C., \& Faccenda, O. (2012). Sintomas depressivos em idosos: Análise dos itens da Escala de Depressão Geriátrica [Depressive symptoms in the elderly: Analysis of the items of the Geriatric Depression Scale]. Acta Paulista de Enfermagem, 25(4), 497-503. doi:10.1590/S0103-21002012000400003
Assis, L.O. (2014). Propriedades psicométricas do questionário de atividades de vida diária de Pfeffer [Psychometric properties of the Pfeffer's functional activities questionnaire] (Doctoral dissertation). Retrieved from http://www.bibliotecadigital.ufmg.br/ dspace/handle/1843/BUBD-9VNG4Q

Associação Brasileira de Empresas de Pesquisa. (2010). $O$ novo critério padrão de classificação econômica Brasil. Retrieved from http://www.abep.org/criterio-brasil

Beck, A.T., Rush, A.J., Shaw, B.F., \& Emery, G. (1979). Cognitive therapy of depression: A treatment manual. New York, NY: Guilford.

Brucki, S. M. D., Nitrini, R., Caramelli, P., Bertolucci, P. H. F., \& Okamoto, I. H. (2003). Sugestões para o uso do mini-exame do estado mental no Brasil [Suggestions for utilization of the mini-mental state examination in Brazil]. Arquivos de Neuropsiquiatria, 61(3B), 777-781. doi:10.1590/S0004-282X2003000500014

Cunha, J. A. (2001). Manual da versão em português das Escalas Beck [Manual of the Portuguese version of Beck Inventories]. São Paulo, SP: Casa do Psicólogo.

d'Orsi, E., Xavier, A. J., \& Ramos, L. R. (2011). Trabalho, suporte social e lazer protegem idosos da perda funcional: Estudo epidoso [Work, social support and leisure protect the elderly from functional loss: Epidos study]. Revista de Saúde Pública, 45(4), 685-692. doi:10.1590/S003489102011000400007

Ferreira, H. G. (2015). Propriedades psicométricas de um instrumento para avaliar o envolvimento de idosos em atividades prazerosas [Psychometric properties of an instrument to assess older people's involvement in pleasant events] (Doctoral dissertation). Retrieved from http://www. ppgpsi.ufscar.br/tese-heloisa-goncalves-ferreira/view

Ferreira, H. G., \& Barham, E. J. (2011). O envolvimento de idosos em atividades prazerosas: Revisão de literatura sobre instrumentos de aferição [Elderly people's involvement in pleasant activities: A literature review on measurement instruments]. Revista Brasileira de Geriatria e Gerontologia, 14(3), 579-590.doi:10.1590/ S1809-98232011000300017

Ferreira, H. G., \& Barham, E. J. (2013). Adaptação transcultural de um instrumento para avaliar o envolvimento de idosos em atividades prazerosas [Crosscultural adaptation of an instrument to evaluate older people's involvement in pleasant activities]. Cadernos de Saúde Pública, 29(12), 2554-2560. doi:10.1590/0102$311 \mathrm{X} 00130212$

Ferreira, H. G., Barham, E. J., \& Fontaine, A. M. G. V. (2015). A measure to assess Brazilians' involvement in pleasant activities: Initial evidence of internal and external validity. Clinical Gerontologist, 38(5), 375-394. doi:10.1080/07317115.2015.1067270 
Fundação Seade. (2010). Índice Paulista de Vulnerabilidade Social - IPVS. Retrieved from http://www.seade.gov. br/analises_estudos/indice-paulista-de-vulnerabilidadesocial-ipvs-versao-2010/

Gomes-Oliveira, M. H., Gorenstein, C., Lotufo Neto, F., Andrade, L. H., \& Wang, Y. P. (2012). Validation of the Brazilian Portuguese version of the Beck Depression Inventory - II in a community sample. Revista Brasileira de Psiquiatria, 34(4), 389-394. doi:10.1016/j. rbp.2012.03.005

Lewinsohn, P. M., \& Graf, M. (1973). Pleasant activities and depression. Journal of Consulting and Clinical Psychology, 41(2), 261-268. doi:10.1037/h0035142

Lewinsohn, P. M., \& Libet, J. (1972). Pleasant events, activity schedules, and depressions. Journal of Abnormal Psychology, 79(3), 291-295. Retrieved from http:// psycnet.apa.org/fulltext/1973-02672-001.pdf

Márquez-González, M., Losada, A., Rider, K. L., \& LópezPérez, B. (2014). Spanish validation of the California Older Person's Pleasant Events Schedule (COPPES). Clinical Gerontologist, 37(2), 151-166. doi:10.1080/073 17115.2013.868851

Martin, P., Kelly, N., Kahana, B., Kahana, E., Willcox, B. J., Willcox, D. C., \& Poon, L. W. (2015). Defining successful aging: A tangible or elusive concept? The Gerontologist, 55(1), 14-25. doi:10.1093/geront/gnu044

Neri, A. L. (2007). Qualidade de vida na velhice e subjetividade [Quality of life during aging and subjectivity]. In A. L. Neri (Org.), Qualidade de vida na velhice: Enfoque multidisciplinar [Quality of life during aging: A multidisciplinary focus] (pp. 15-59). São Paulo, SP: Alínea.

Pfeffer, R. I., Kurosaki, T. T., Harrah, C. H., Jr., Chance, J. M., $\&$ Filos, S. (1982). Measurement of functional activities in older adults in the community. Journal of Gerontology, 37(3), 323-329. doi:10.1093/geronj/37.3.323

Pinto, F. N. F. R., \& Oliveira, D. C. (2015). Capacidade funcional e envolvimento social em idosos: Há relação? [Functional capacity and social involvement in elderly: There is relationship?]. Revista Brasileira de Ciências do Envelhecimento Humano, 12(1), 56-68. doi:10.5335/ rbceh.v12i1.4687

Pinto, J. M., \& Neri, A. L. (2013). Doenças crônicas, capacidade funcional, envolvimento social e satisfação em idosos comunitários: Estudo fibra [Chronic diseases, functional ability, social involvement and satisfaction in community-dwelling elderly: The Fibra study]. Ciência \& Saúde Coletiva, 18(12), 3449-3460. doi:10.1590/ S1413-81232013001200002

Rider, K. L., Gallagher-Thompson, D., \& Thompson, L. W. (2004). California Older Person's Pleasant Events Schedule: Manual. Retrieved from http://med.stanford. edu/oafc/coppes_files/Manual2.pdf
Rider, K. L., Gallagher-Thompson, D., \& Thompson, L. W. (2016). California Older Person's Pleasant Events Schedule: A tool to help older adults increase positive experiences. Clinical Gerontologist, 39(1), 64-83. doi:1 $0.1080 / 07317115.2015 .1101635$

Rowe, J. R., \& Kahn, R. L. (1998). Successful aging. New York, NY: Pantheon.

Sato, S., Demura, S., Kobayashi, H., \& Nagasawa, Y. (2002). The relationship and its change with aging between ADL and daily life satisfaction characteristics in independent Japanese elderly living at home. Journal of Physiological Anthropology and Applied Human Science, 21(4), $195-$ 204. doi:10.2114/jpa.21.195

Heloísa Gonçalves Ferreira is a Professor of the Instituto de Educação, Letras, Artes, Ciências Humanas e Sociais of the Universidade Federal do Triângulo Mineiro.

Elizabeth Joan Barham is a Professor of the Centro de Educação e Ciências Humanas of the Universidade Federal de São Carlos.

Received: Aug. 10, 2016

1st Revision: Jan. 17, 2017

Approved: Mar. 22, 2017

How to cite this article:

Ferreira, H. G., \& Barham, E. J. (2018). Relationships between pleasant events, depression, functionality and socio-demographic variables in the elderly. Paidéia (Ribeirão Preto), 28, e2815. doi:http://dx.doi.org/10.1590/1982-4327e2815 